\title{
Patterns of Nutrient Intake among Male and Female High School-Aged Cross-Country Skiers and Speed Skaters
}

\author{
Tae-Woong $0{ }^{1}$, Sanae $0 k^{2} b^{2}{ }^{2}$, Sakura Tanaka ${ }^{3}$, Tatsuki Naka ${ }^{4}$ \\ ${ }^{1}$ Department of Sport Leisure, College of Sport Sciences, Yongin University, Yongin-Si, Korea \\ ${ }^{2}$ Nagano Prefectural Children's Hospital Medical Technology Division Nutrition Department, Azumio-Shi, Japan \\ ${ }^{3}$ Department of Sport Science, College of Sport Sciences, Nippon Sport Science University, \\ Kamoshida-Cho, Japan \\ ${ }^{4}$ Department of Sports and Fitness, Faculty of Wellness, Shigakkan University, Obu-City, Japan \\ Email: ohtw1972@gmail.com
}

How to cite this paper: Oh, T.-W., Okubo, S., Tanaka, S. and Naka, T. (2018) Patterns of Nutrient Intake among Male and Female High School-Aged Cross-Country Skiers and Speed Skaters. Food and Nutrition Sciences, 9, 119-135.

https://doi.org/10.4236/fns.2018.92010

Received: December 22, 2017

Accepted: February 23, 2018

Published: February 26, 2018

Copyright (๑) 2018 by authors and Scientific Research Publishing Inc. This work is licensed under the Creative Commons Attribution International License (CC BY 4.0).

http://creativecommons.org/licenses/by/4.0/

\begin{abstract}
This study aimed to determine the appropriate nutritional intakes and dietary habits of high school-aged cross-country skiers and speed skaters. The subjects, all high school students from $\mathrm{N}$ Prefecture, included 18 male cross-country skiers, 5 male speed skaters, 10 female cross-country ski players and 4 female speed skaters. Physical measurements, food intake frequency survey results, bone mineral density and exercise stress test outcomes, and lactic acid measurements were evaluated. Female athletes in both sports had higher body fat percentages relative to the average range stated for female athletes. Male speed skaters had a significantly higher maximum oxygen intake than that male cross-country skiers did. By contrast, this parameter did not differ significantly among female athletes. A negative correlation was observed between the fat free mass and muscle mass, and a positive correlation was observed among the body fat percentage, fat percentage, and fat mass. Both male and female athletes had protein intake ratios within the reference ranges. All athletes except male speed skaters had lipid energy ratios that were higher than the upper limit of the reference value. Both male and female athletes also reported carbohydrate energy ratios within the reference ranges, but had cereal energy ratios below the reference values. Athletes should pay attention to the ingestion of various nutrients to ensure a sufficient energy intake. Accordingly, adolescent athletes should consume daily meals containing a good balance of staple foods, main dishes, side dishes, milk and other dairy products, and fruits.
\end{abstract}




\section{Keywords}

Nutrient Intake, High School, Cross-Country Skiers, Speed Skaters

\section{Introduction}

Athletes' eating and drinking habits are thought to affect sports conditioning, fatigue recovery, and performance [1]. The finding that junior athletes aim to emulate the dietary habits, particularly those pursuing highest levels of participation worldwide, serves as a testament to the high global level of awareness of diet [2]. Regarding high-level athletes [3], professional baseball players [4] are required to consume timely meals that accommodate daily and seasonal schedules. Although sports players are aware of the importance of diet [5], many experience problems with eating and drinking habits and a lack of sleep [6]. Previous reports have described the nutritional situations of groups of college and university athletes participating in karate, tennis, gymnastics, and soccer [7] [8] [9] [10]. Currently, however, official criteria for nutritional intakes are not publicly available to the Japanese population [11]. Although athletes may be aware that their intakes of some food groups may be lacking, they are also aware that they do not make efforts to consume these items [12]. Despite recognizing the need for proper nutrition, very few athletes work from a basis of correct knowledge and skills. High school athletes are expected to play a vital role in improving fitness and nutritional knowledge, health maintenance, conditioning, failure prevention, and athletic skills improvement, which will promote the nurturing of enriched and healthy humans [13]. This study aimed to examine the intakes of nutrients among high school students by examining the intakes and eating habits of skiers and speed skaters in this population.

\section{Materials and Methods}

The study included 18 male cross-country skiers, 5 speed skaters, 10 cross-country skaters, 10 ski-skaters, and four high-speed skaters who attended high school. This study received approval from the Matsumoto University of Science and Technology Committee. The height and weight of each athlete was measured. The body mass index (BMI) was then calculated from these measurements. The body composition parameters of body fat percentage, fat quantity, lean and fat body weights, and muscle mass were measured using a body fat meter (BC-11 E; Tanita, Tokyo, Japan).The stiffness index, a measure of bone density, was measured by using LUNAR, A-001, and A-1000LS (GE Medical Systems, Madison, WI, USA) (Table 1). The maximum oxygen intake amount was measured using an exhalation gas analyzer (AERO MONITOR AE 3000S). The athletes were subjected to multi-step exercise load tests, in which the loads were gradually increased. Blood lactate concentrations were measured as a simple lactic acid measurement from a fingertip blood sample using Lactate Pro II (Arkray Co., 
Table 1. Body composition data.

\begin{tabular}{ccccc}
\hline & \multicolumn{2}{c}{ Cross-country skiers } & \multicolumn{2}{c}{ Speed skaters } \\
\cline { 2 - 5 } & Male & Female & Boys & Girls \\
\cline { 2 - 5 } & $(\mathrm{n}=18)$ & $(\mathrm{n}=10)$ & $(\mathrm{n}=5)$ & $(\mathrm{n}=4)$ \\
\hline Age (years) & $16.2 \pm 1.4$ & $15.8 \pm 1.0$ & $17.0 \pm 1.0$ & $16.0 \pm 0.8$ \\
Body height $(\mathrm{cm})$ & $170.2 \pm 6.9$ & $159.0 \pm 3.3^{\mathrm{ab}}$ & $170.8 \pm 6.3$ & $159.3 \pm 8.3^{\mathrm{ab}}$ \\
Body weight $(\mathrm{kg})$ & $60.3 \pm 7.2$ & $53.4 \pm 5.1^{\mathrm{ab}}$ & $59.6 \pm 7.9$ & $56.8 \pm 2.1^{\mathrm{ab}}$ \\
Body mass index $\left(\mathrm{kg} / \mathrm{m}^{2}\right)$ & $20.8 \pm 1.9$ & $21.2 \pm 1.7$ & $20.3 \pm 1.5$ & $22.2 \pm 2.0$ \\
Percent of body fat $(\%)$ & $11.5 \pm 4.1$ & $25.1 \pm 4.4^{\mathrm{ab}}$ & $8.9 \pm 2.0$ & $29.4 \pm 4.5^{\mathrm{ab}}$ \\
Body fat mass $(\mathrm{kg})$ & $7.1 \pm 3.1$ & $13.6 \pm 3.5^{\mathrm{ab}}$ & $5.4 \pm 1.7$ & $16.7 \pm 2.6^{\mathrm{ab}}$ \\
Lean body mass $(\mathrm{kg})$ & $51.6 \pm 10.4$ & $40.0 \pm 2.0^{\mathrm{ab}}$ & $54.2 \pm 6.2$ & $40.1 \pm 2.8$ \\
Skeletal muscle mass $(\mathrm{kg})$ & $50.4 \pm 5.1$ & $37.6 \pm 1.8^{\mathrm{ab}}$ & $51.4 \pm 5.9$ & $37.8 \pm 2.5$ \\
Stiffness index & $116.1 \pm 14.3$ & $116.9 \pm 11.5$ & $109.4 \pm 21.6$ & $119.0 \pm 18.5^{\mathrm{ab}}$ \\
Physical activity level & $2.8 \pm 0.6$ & $2.6 \pm 0.4$ & $2.9 \pm 0.1$ & $2.8 \pm 0.1$ \\
\hline
\end{tabular}

Values are shown as means \pm standard deviations for individual groups. Total $\mathrm{n}=37$. ${ }^{\mathrm{a}} p<0.05$ vs. male cross-country skiers. ${ }^{\mathrm{b}} p<0.05$ vs. male speed skaters.

Ltd., Muntinlupa City, Philippines).

The meal survey was distributed on the same day as the physical measurements. All participants monitored their meal intakes for 1 or 2 months using the food intake frequency survey method developed by Takahashi et al. (FFQg) [14]. Each participant self-recorded the time spent in daily life activities to determine the physical activity level, and these data were used to estimate the required amount of energy. Nutrient intakes were compared with the Japanese dietary standard: 2.00 (1.90 to 2.20) [15].

The standard value at the time of the study was based on the Japanese meal intake standard (2010 version) with a physical activity level of $2.00(1.90-2.20)$. The amount of consumed energy was compared with the estimated energy requirement for the standard Japanese diet: $2.00(1.90-2.20)$ and the high energy requirement. A dispersion analysis, performed using the verification method, determined a difference of $<5 \%$ (SPSS $11.0 \mathrm{~J}$ ).

\section{Results}

\subsection{Body Compositions of the Subjects}

The average heights and weights of the subjects were compared to those from a national health and nutrition survey in 2012. The female speed skaters had a higher average weight relative to the 2012 national survey results. Significant sex-related differences were observed in body fat ratios. In addition, the physical activity level (PAL) of participants in the study exceeded the PAL of 2.0 for the body activity level in the Japanese Standards for Food Intake (2010 Edition). No significant differences were observed among participants or between sexes in terms of stiffness index values. 


\subsection{Maximum Oxygen Intake, Heart Rate, and Blood Glucose Level}

Table 2 presents the maximum oxygen intake, heart rate, and blood lactate values at the highest blood pressure achieved when using a treadmill. Among male study participants, speed skaters had a significantly higher average maximum oxygen intake per kg body weight, compared with cross-country skiers. By contrast, no significant difference was observed among female athletes. We established a clear relationship between the $\mathrm{VO}_{2} \max$, body fat percentage, fat quantity, fat amount, and muscle mass. The free fat mass correlated positively with the muscle mass, whereas the body fat percentage correlated negatively with the fat mass. As shown in Figure 1, a higher the body fat percentage, corresponded to a lower $\mathrm{VO}_{2} \max$, whereas a higher the fat free mass corresponded to a higher $\mathrm{VO}_{2}$ max. The maximum heart rate at the peak maximal oxygen uptake did not differ significantly among the groups of athletes. The highest lactic acid level indicates the extent to which the lactic acid mechanism is mobilized during the energy acquisition process of a muscle contraction. The energy during short-interval maximum exercise is thought to depend mainly on a glycolytic supply [16]. Accordingly, from the aspect of intermediate metabolism, the highest blood lactic acid value measured after the end of the exercise is used to estimate the anaerobic exercise ability index [17] and anaerobic energy expenditure [18]. In

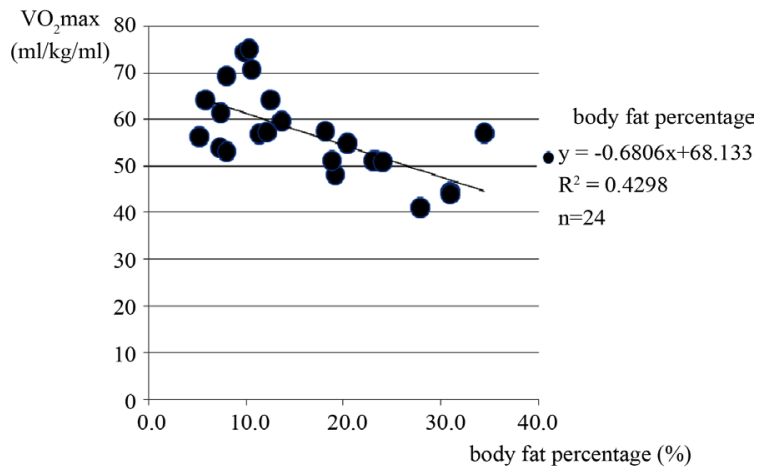

(a)

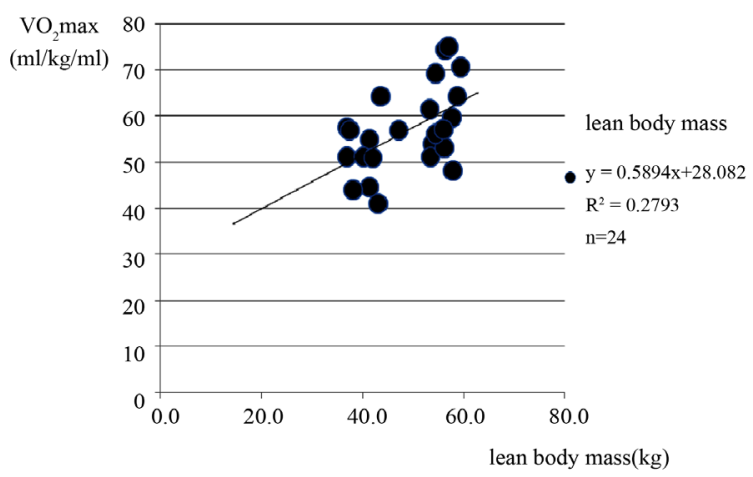

(b)

Figure 1. Relationships of $\mathrm{VO}_{2}$ max with (a) the measured body fat percentage and (b) the measured lean body mass. 
Table 2. Maximum oxygen uptake $\left(\mathrm{VO}_{2} \mathrm{max}\right)$, maximum heart rate (HRmax), and lactate levels.

\begin{tabular}{ccccc}
\hline & \multicolumn{2}{c}{ Cross-country skiers } & \multicolumn{2}{c}{ Speed skaters } \\
\cline { 2 - 5 } & Male & Female & Male & Female \\
\cline { 2 - 5 } & $(\mathrm{n}=11)$ & $(\mathrm{n}=8)$ & $(\mathrm{n}=5)$ & $(\mathrm{n}=4)$ \\
\hline $\mathrm{VO}_{2} \max (\mathrm{ml} / \mathrm{kg} / \mathrm{min})$ & $56.2 \pm 4.8$ & $51.8 \pm 4.9$ & $70.8 \pm 4.4^{\mathrm{abc}}$ & $48.2 \pm 7.2$ \\
$\mathrm{HRmax}(\mathrm{bpm})$ & $200.6 \pm 10.9$ & $186.4 \pm 5.1$ & $193.0 \pm 6.9$ & $194.0 \pm 7.7$ \\
Lactate $(\mathrm{mM})$ & $10.8 \pm 2.0$ & $11.0 \pm 3.2$ & $14.9 \pm 4.3$ & $15.4 \pm 3.2$ \\
\hline
\end{tabular}

Values are shown as means \pm standard deviations for individual groups. Total $\mathrm{n}=28$. ${ }^{\mathrm{a}} p<0.05$ vs. male cross-country skiers. ${ }^{\mathrm{b}} p<0.05$ vs. male speed skaters. ${ }^{c} p<0.05$ vs. female speed skaters.

this study, no significant inter-group differences were observed in the highest lactic acid intake levels.

\subsection{Energy and Nutrient Intake}

Tables 3-6 present the daily energy amounts and nutrient intakes of the subjects, while and Figure 2 presents the intake ratios by sex and sport type (In/St) with respect to the recommended dietary allowance (RDA), adequate intake (AI), and tentative dietary goal for preventing lifestyle-related diseases (DG) for each nutrient according to the Japanese dietary intake standard (2010 version). The intake of the three major nutrients was small in all groups. All groups reported a higher-than-baseline protein intake. The lipid intake amount met the DG in all groups except for male speed skaters. None of the groups met the standard carbohydrate intake value.

\subsection{Nutrition Ratio}

Table 7 lists the intake ratio of each nutrient and food. In all groups, the protein energy ratio was within the range. In all groups except speed skaters, the lipid energy ratio was equal to or exceeded the upper limit of the DG for fat energy. In all groups, the carbohydrate energy ratio was considered desirable, whereas the grain energy ratios were below the reference values.

\subsection{Ratios of Amounts of Consumed Foods by Food Group to Standard Quantities}

Tables 8-11 present the foods in each food group reported by the survey participants, and the amounts of consumed food by food group are used to determine whether the food composition satisfies the dietary intake criteria. All participant groups reported either an excess or deficiency in various food groups. Regarding sweets, preference drinks, and sugars, all groups had low total In/St values, and the intakes were considered to be lower than the reference values (Tables 8-11). As shown in Tables 12-15, however, the intakes of confectionery were larger than the reference value in all groups, with values of $1.72-3.71$ times higher than those reported for similarly aged men and women. 


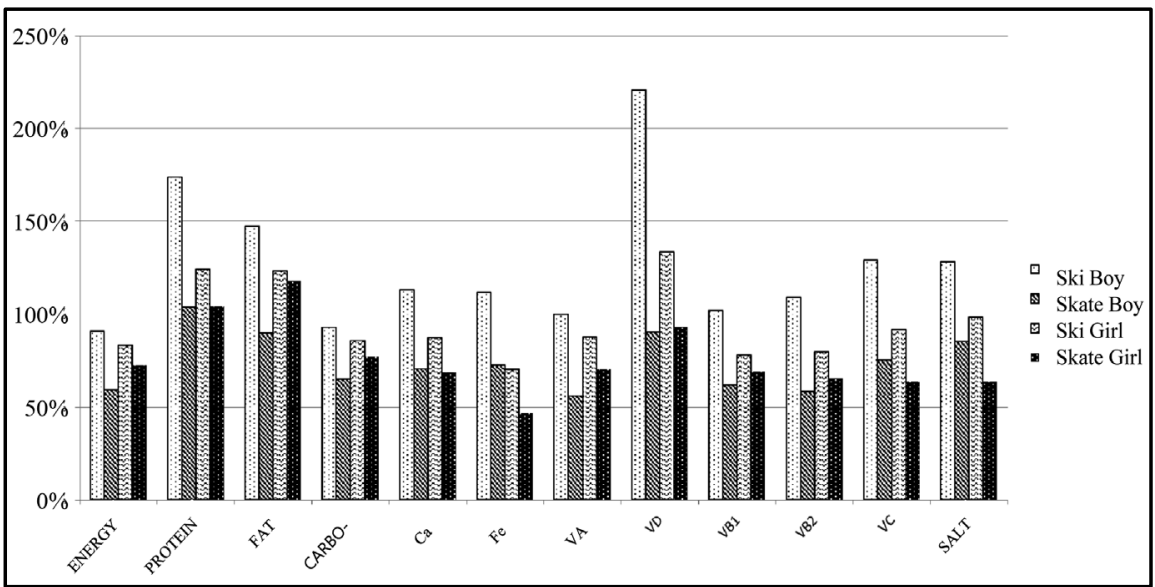

Figure 2. Nutritional intake ratios. Japanese food intake standard (2010); Physical activity level: 3 .

Table 3. Nutritional intakes of male cross-country skiers.

\begin{tabular}{|c|c|c|c|c|c|}
\hline \multirow{3}{*}{ Nutrients } & \multirow{3}{*}{$\begin{array}{l}\text { Intake quantity } \\
(\text { mean } \pm \mathrm{SD})\end{array}$} & \multirow{3}{*}{$\begin{array}{l}\text { In/St } \\
(\%)^{* 1}\end{array}$} & \multirow{3}{*}{$\begin{array}{c}\begin{array}{c}\text { Standard } \\
\text { value }^{\star 2}\end{array} \\
15-17- \\
\text { year-olds }\end{array}$} & \multirow{2}{*}{\multicolumn{2}{|c|}{$\begin{array}{c}\text { National Health Survey and } \\
\text { Nutrition Examination Survey } \\
15 \text { - 19-year-olds }\end{array}$}} \\
\hline & & & & & \\
\hline & & & & Survey results & Ratio $(\%)^{* 4}$ \\
\hline Energy (kcal) & $2735 \pm 533$ & 88 & 3100 & 2504 & 109 \\
\hline Protein (g) & $100.8 \pm 25.3$ & 168 & 60 & 86.1 & 195 \\
\hline Lipid (g) & $98.3 \pm 24.4$ & $143^{* 5}$ & $68.9-103.3$ & 81.2 & 121 \\
\hline Carbohydrate (g) & $349.5 \pm 71.2$ & $90^{\star 6}$ & $387.5-542.5$ & 344.3 & 102 \\
\hline Calcium (mg) & $870.4 \pm 408$ & 109 & 800 & 550 & 158 \\
\hline $\mathrm{Fe}(\mathrm{mg})$ & $10.2 \pm 2.9$ & 107 & 9.5 & 8.2 & 124 \\
\hline Retinol ( $\mu \mathrm{g})$ & $854 \pm 295$ & 95 & 900 & 597 & 143 \\
\hline Vitamin D $(\mu \mathrm{g})$ & $9.6 \pm 5.3$ & 213 & 4.5 & 6.8 & 141 \\
\hline Vitamin $B_{1}(\mathrm{mg})$ & $1.5 \pm 0.5$ & 100 & 1.5 & 1.15 & 130 \\
\hline Vitamin $B_{2}(\mathrm{mg})$ & $1.82 \pm 0.6$ & 107 & 1.7 & 1.37 & 133 \\
\hline Vitamin C (mg) & $120 \pm 66$ & 120 & 100 & 86 & 140 \\
\hline $\begin{array}{l}\text { Total amount } \\
\text { of dietary fiber }(\mathrm{g})\end{array}$ & $15.1 \pm 4.7$ & - & - & 14.1 & 107 \\
\hline Salt (g) & $11.2 \pm 2.8$ & 124 & 9.0 & 11.0 & 102 \\
\hline
\end{tabular}

$\mathrm{n}=18 .{ }^{* 1} \mathrm{In} / \mathrm{St}$ : Intake quantity/Standard value. ${ }^{* 2}$ Japanese food intake standard (2010); Physical activity level: 3. ${ }^{* 3}$ Overview of the National Health Nutrition Survey of the Ministry of Health, Labor, and Welfare in 2012. ${ }^{\star 4}$ Intake ratio of subjects to peers who responded to the National Health and Nutrition Survey of the Ministry of Health, Labor, and Welfare in 2012. ${ }^{* 5}$ The ratio of the lipid intake quantity to the target quantity when the energy ratio is $20 \%{ }^{* 6}$ The ratio of the carbohydrate intake quantity to the target quantity when the energy ratio is $50 \%$.

\subsection{Awareness of Food Habits}

The results of the questionnaire survey are shown in Table 16. In response to the question "Do you know your proper weight?", $>60 \%$ of subjects (excepting 
Table 4. Nutritional intakes of male speed skaters.

\begin{tabular}{|c|c|c|c|c|c|}
\hline \multirow[t]{3}{*}{ Nutrients } & \multirow{3}{*}{$\begin{array}{l}\text { Intake quantity } \\
\quad(\text { mean } \pm S D)\end{array}$} & \multirow{3}{*}{$\begin{array}{l}\text { In/St } \\
(\%)^{* 1}\end{array}$} & \multirow{3}{*}{$\begin{array}{c}\begin{array}{c}\text { Standard } \\
\text { value }^{\star 2}\end{array} \\
15 \text { - } 17 \text {-year-olds }\end{array}$} & \multirow{2}{*}{\multicolumn{2}{|c|}{$\begin{array}{c}\text { National Health Survey and } \\
\text { Nutrition Examination Survey } \\
15 \text { - 19-year-olds }\end{array}$}} \\
\hline & & & & & \\
\hline & & & & Survey results & Ratio $(\%)^{* 4}$ \\
\hline Energy (kcal) & $1852 \pm 371$ & 60 & 3100 & 2504 & 74 \\
\hline Protein (g) & $62.1 \pm 19.8$ & 104 & 60 & 86.1 & 72 \\
\hline Lipid (g) & $61.9 \pm 19.2$ & $90^{\star 5}$ & $68.9-103.3$ & 81.2 & 76 \\
\hline Carbohydrate (g) & $253.2 \pm 38.9$ & $65^{\star 6}$ & $387.5-542.5$ & 344.3 & 74 \\
\hline Calcium (mg) & $565 \pm 276$ & 71 & 800 & 550 & 103 \\
\hline $\mathrm{Fe}(\mathrm{mg})$ & $6.9 \pm 3.4$ & 73 & 9.5 & 8.2 & 84 \\
\hline Retinol $(\mu \mathrm{g})$ & $504 \pm 230$ & 56 & 900 & 597 & 84 \\
\hline Vitamin D $(\mu \mathrm{g})$ & $4.1 \pm 1.9$ & 91 & 4.5 & 6.8 & 60 \\
\hline Vitamin $B_{1}(\mathrm{mg})$ & $0.92 \pm 0.3$ & 61 & 1.5 & 1.15 & 80 \\
\hline Vitamin $B_{2}(\mathrm{mg})$ & $0.99 \pm 0.3$ & 58 & 1.7 & 1.37 & 72 \\
\hline Vitamin C (mg) & $75 \pm 44$ & 75 & 100 & 86 & 87 \\
\hline $\begin{array}{l}\text { Total amount } \\
\text { of dietary fiber }(\mathrm{g})\end{array}$ & $9.9 \pm 4.6$ & - & - & 14.1 & 70 \\
\hline Salt (g) & $7.4 \pm 2.6$ & 82 & 9.0 & 11.0 & 67 \\
\hline
\end{tabular}

$\mathrm{n}=5 .{ }^{* 1} \mathrm{In} / \mathrm{St}$ : Intake quantity/Standard value. ${ }^{* 2}$ Japanese food intake standard (2010); Physical activity level: 3 . ${ }^{* 3}$ Overview of the National Health Nutrition Survey of the Ministry of Health, Labor, and Welfare in 2012. ${ }^{*}$ Intake ratio of subjects to peers who responded to the National Health and Nutrition Survey of the Ministry of Health, Labor, and Welfare in $2012 .{ }^{* 5}$ The ratio of the lipid intake quantity to the target quantity when the energy ratio is $20 \% .{ }^{* 6}$ The ratio of the carbohydrate intake quantity to the target quantity when the energy ratio is $50 \%$.

Table 5. Nutritional intakes of female cross-country skiers.

\begin{tabular}{|c|c|c|c|c|c|}
\hline \multirow{3}{*}{ Nutrients } & \multirow{3}{*}{$\begin{array}{l}\text { Intake quantity } \\
(\text { mean } \pm S D)\end{array}$} & \multirow{3}{*}{$\begin{array}{l}\text { In/St } \\
(\%)^{* 1}\end{array}$} & \multirow{2}{*}{\multicolumn{3}{|c|}{$\begin{array}{c}\text { National Health Survey and } \\
\text { Standard value }{ }^{* 2} \frac{\text { Nutrition Examination Survey }}{{ }^{* 3}} \\
15-19 \text {-year-olds }\end{array}$}} \\
\hline & & & & & \\
\hline & & & 15 - 17-year-olds & Survey results & Ratio $(\%)^{* 4}$ \\
\hline Energy (kcal) & $2081 \pm 371$ & 83 & 2500 & 1828 & 114 \\
\hline Protein (g) & $68.4 \pm 19.8$ & 124 & 55 & 66.5 & 103 \\
\hline Lipid (g) & $68.7 \pm 19.2$ & $124^{* 5}$ & $55.6-83.3$ & 62.3 & 110 \\
\hline Carbohydrate (g) & $267.2 \pm 38.9$ & $86^{* 6}$ & $312.5-437.5$ & 242.8 & 110 \\
\hline Calcium (mg) & $568 \pm 276$ & 87 & 650 & 456 & 125 \\
\hline $\mathrm{Fe}(\mathrm{mg})$ & $7.4 \pm 3.4$ & 70 & 10.5 & 6.7 & 110 \\
\hline Retinol ( $\mu \mathrm{g})$ & $570 \pm 230$ & 88 & 650 & 491 & 116 \\
\hline Vitamin D $(\mu \mathrm{g})$ & $6.0 \pm 1.9$ & 133 & 4.5 & 6.0 & 100 \\
\hline Vitamin $B_{1}(m g)$ & $0.9 \pm 0.3$ & 75 & 1.2 & 0.87 & 115 \\
\hline Vitamin $B_{2}(m g)$ & $1.1 \pm 0.3$ & 79 & 1.4 & 1.1 & 100 \\
\hline Vitamin C (mg) & $91.0 \pm 44$ & 91 & 100 & 78 & 117 \\
\hline $\begin{array}{c}\text { Total amount } \\
\text { of dietary fiber }(\mathrm{g})\end{array}$ & $12.4 \pm 4.6$ & - & - & 12.3 & 100 \\
\hline Salt (g) & $7.4 \pm 2.6$ & 99 & 7.5 & 9.0 & 82 \\
\hline \multicolumn{6}{|c|}{$\begin{array}{l}=10 .{ }^{* 1} \text { In/St: Intake quantity/Standard value. }{ }^{* 2} \text { Japanese food intake standard (2010); Physical activity } \\
\text { evel: } 3 .{ }^{* 3} \text { Overview of the National Health Nutrition Survey of the Ministry of Health, Labor, and Welfare } \\
\text { n 2012.. }{ }^{* 4} \text { Intake ratio of subjects to peers who responded to the National Health and Nutrition Survey of } \\
\text { he Ministry of Health, Labor, and Welfare in } 2012 .{ }^{* 5} \text { The ratio of the lipid intake quantity to the target } \\
\text { uantity when the energy ratio is } 20 \% .{ }^{* 6} \text { The ratio of the carbohydrate intake quantity to the target quantity } \\
\text { vhen the energy ratio is } 50 \% \text {. }\end{array}$} \\
\hline
\end{tabular}


Table 6. Nutritional intakes of female speed skaters.

\begin{tabular}{|c|c|c|c|c|c|}
\hline \multirow[t]{2}{*}{ Nutrients } & \multirow[t]{2}{*}{$\begin{array}{l}\text { Intake quantity } \\
(\text { mean } \pm S D)\end{array}$} & \multirow[t]{2}{*}{$\begin{array}{l}\text { In/St } \\
(\%)^{* 1}\end{array}$} & \multicolumn{3}{|c|}{$\begin{array}{c}\text { Standard value }{ }^{\star 2} \frac{\begin{array}{c}\text { Nutritional Health Survey and } \\
\text { Examination Survey }\end{array}}{15-19 \text {-year-olds }} \\
\end{array}$} \\
\hline & & & 15 - 17-year-olds & Survey results & Ratio $(\%)^{* 4}$ \\
\hline Energy (kcal) & $1816 \pm 360$ & 73 & 2500 & 1828 & 99 \\
\hline Protein (g) & $57.3 \pm 15.0$ & 104 & 55 & 66.5 & 86 \\
\hline Lipid (g) & $65.5 \pm 24.4$ & $118^{\star 5}$ & $55.6-83.3$ & 62.3 & 105 \\
\hline Carbohydrate (g) & $240.1 \pm 42.4$ & $77^{\star 6}$ & $312.5-437.5$ & 242.8 & 99 \\
\hline Calcium (mg) & $444 \pm 188$ & 68 & 650 & 456 & 97 \\
\hline $\mathrm{Fe}(\mathrm{mg})$ & $4.9 \pm 1.4$ & 47 & 10.5 & 6.7 & 73 \\
\hline Retinol ( $\mu \mathrm{g})$ & $457 \pm 164$ & 70 & 650 & 491 & 93 \\
\hline Vitamin D $(\mu \mathrm{g})$ & $4.2 \pm 1.7$ & 93 & 4.5 & 6.0 & 70 \\
\hline Vitamin $B_{1}(\mathrm{mg})$ & $0.8 \pm 0.3$ & 69 & 1.2 & 0.87 & 95 \\
\hline Vitamin $B_{2}(\mathrm{mg})$ & $0.9 \pm 0.3$ & 66 & 1.4 & 1.1 & 84 \\
\hline Vitamin C (mg) & $64 \pm 21$ & 64 & 100 & 78 & 82 \\
\hline $\begin{array}{c}\text { Total amount } \\
\text { of dietary fiber (g) }\end{array}$ & $8.0 \pm 2.4$ & - & - & 12.3 & 65 \\
\hline Salt (g) & $4.8 \pm 1.1$ & 64 & 7.5 & 9.0 & 53 \\
\hline
\end{tabular}

$\mathrm{n}=4 .{ }^{* 1} \mathrm{In} /$ St: Intake quantity/Standard value. ${ }^{\star 2}$ Japanese food intake standard (2010); Physical activity level: 3. ${ }^{* 3}$ Overview of the National Health Nutrition Survey of the Ministry of Health, Labor, and Welfare in 2012. ${ }^{* 4}$ Intake ratio of subjects to peers who responded to the National Health and Nutrition Survey of the Ministry of Health, Labor, and Welfare in $2012 .{ }^{* 5}$ The ratio of the lipid intake quantity to the target quantity when the energy ratio is $20 \%$. ${ }^{* 6}$ The ratio of the carbohydrate intake quantity to the target quantity when the energy ratio is $50 \%$.

Table 7. Nutrition and food intake ratios.

\begin{tabular}{|c|c|c|c|c|c|}
\hline & \multicolumn{4}{|c|}{ Intake situation } & \multirow{3}{*}{ Standard value } \\
\hline & \multicolumn{2}{|c|}{ Cross-country skiers } & \multicolumn{2}{|c|}{ Speed skaters } & \\
\hline & Male & Female & Male & Female & \\
\hline Protein energy ratio & $14.8 \pm 2.0$ & $13.8 \pm 1.9$ & $13.2 \pm 2.5$ & $12.6 \pm 2.3$ & $10 \%<20 \%$ \\
\hline Lipid energy ratio & $32.7 \pm 4.1$ & $32.1 \pm 3.8$ & $29.6 \pm 3.8$ & $31.6 \pm 7.9$ & $20 \%<30 \%$ \\
\hline Carbohydrate energy ratio & $52.5 \pm 5.4$ & $54.1 \pm 4.9$ & $57.1 \pm 6.1$ & $55.8 \pm 9.4$ & $50 \%<70 \%$ \\
\hline Cereal energy ratio & $31.7 \pm 7.6$ & $34.0 \pm 5.4$ & $39.5 \pm 7.9$ & $41.9 \pm 12.5$ & $50 \%-60 \%{ }^{\star 2}$ \\
\hline $\begin{array}{l}\text { Animal protein energy } \\
\text { ratio }\end{array}$ & $61.7 \pm 9.2$ & $54.9 \pm 6.2$ & $52.1 \pm 11.9$ & $61.2 \pm 10.5$ & $40 \%-50 \%{ }^{\star 2}$ \\
\hline
\end{tabular}

Values are shown as means \pm standard deviations. ${ }^{* 1}$ Japanese food intake standard $(2010){ }^{* 2}$ Standard values recommended in Excel Nutrition.

male cross-country skiers) answered "I know". More than $80 \%$ of all target groups responded that "meal time has been determined" to a question regarding food attitudes. Also, in response to the question "Do you eat meals?" Everyone responds that they do not do anything. Regarding whether the amount of snacking was adequate, $>40 \%$ of the respondents answered, "Don't you know?" 
Table 8. Food intakes of male cross-country skiers.

\begin{tabular}{|c|c|c|c|c|c|}
\hline \multirow[t]{2}{*}{ Nutrition } & \multirow{2}{*}{$\begin{array}{c}\text { Intake } \\
\text { quantity } \\
(\text { mean } \pm \mathrm{SD})\end{array}$} & \multirow[t]{2}{*}{$\begin{array}{l}\text { In/St } \\
(\%)^{* 1}\end{array}$} & \multirow[t]{2}{*}{$\begin{array}{l}\text { Standard } \\
\text { value } \\
(\mathrm{g})^{\star 2}\end{array}$} & \multicolumn{2}{|c|}{$\begin{array}{c}\text { National Health Survey and } \\
\text { Nutrition Examination Survey } \\
15 \text { - 19-year-olds }\end{array}$} \\
\hline & & & & Intake quantity & Ratio $(\%)^{* 4}$ \\
\hline Cereals & $515 \pm 118$ & 69 & 750 & 650 & 79 \\
\hline Corms & $44 \pm 29$ & 49 & 90 & 58 & 76 \\
\hline Brightly colored vegetables & $101 \pm 57$ & 67 & 150 & 84 & 120 \\
\hline Other vegetables and mushrooms $s^{* 5}$ & $126 \pm 83$ & 39 & 320 & 181 & 70 \\
\hline Seaweed & $7 \pm 4$ & 35 & 20 & 9 & 78 \\
\hline Beans & $64 \pm 44$ & 64 & 100 & 50 & 128 \\
\hline Seafood & $87 \pm 54$ & 73 & 120 & 55 & 158 \\
\hline Meat & $184 \pm 62$ & 153 & 120 & 167 & 110 \\
\hline Eggs & $43 \pm 24$ & 54 & 80 & 50 & 86 \\
\hline Milk & $385 \pm 261$ & 154 & 250 & 179 & 215 \\
\hline Fruits & $116 \pm 169$ & 53 & 220 & 93 & 125 \\
\hline $\begin{array}{c}\text { Confectionary, } \\
\text { Taste Beverage, Sugar }{ }^{* 5}\end{array}$ & $286 \pm 134$ & 51 & 557 & 496 & 58 \\
\hline Oils, Seeds $s^{\star 5}$ & $28 \pm 35$ & 140 & 20 & 18 & 156 \\
\hline Seasonings, Spices & $41 \pm 14$ & 70 & 90 & 90 & 46 \\
\hline
\end{tabular}

$\mathrm{n}=18 .{ }^{* 1}$ In/St: Intake quantity/Standard value. ${ }^{* 2}$ Excel Nutrition Food Frequency Survey; Standard Value by FFQ Ver. 3.5. ${ }^{* 3}$ Overview of the National Health Nutrition Survey of the Ministry of Health, Labor, and Welfare in 2012. ${ }^{* 4}$ Intake ratio of subjects to 15 - 19-year-old participants in the National Health and Nutrition Survey result from the Ministry of Health, Labor, and Welfare in 2012. ${ }^{* 5} \mathrm{Classified}$ as a similar nutrient food group; the intake amount was set as the total value.

Table 9. Food intakes of male speed skaters.

\begin{tabular}{|c|c|c|c|c|c|}
\hline \multirow[t]{2}{*}{ Nutrition } & \multirow{2}{*}{$\begin{array}{c}\text { Intake } \\
\text { quantity } \\
(\text { mean } \pm S D)\end{array}$} & \multirow{2}{*}{$\begin{array}{l}\text { In/St } \\
(\%)^{* 1}\end{array}$} & \multirow{2}{*}{$\begin{array}{l}\text { Standard } \\
\text { value } \\
(\mathrm{g})^{* 2}\end{array}$} & \multicolumn{2}{|c|}{$\begin{array}{c}\text { National Health Survey and } \\
\text { Nutrition Examination Survey } \\
15 \text { - 19-year-olds }\end{array}$} \\
\hline & & & & Intake quantity & ratio $(\%)^{* 4}$ \\
\hline Cereals & $420 \pm 53$ & 56 & 750 & 650 & 65 \\
\hline Corms & $19 \pm 21$ & 21 & 90 & 58 & 33 \\
\hline Brightly colored vegetables & $65 \pm 47$ & 43 & 150 & 84 & 77 \\
\hline Other vegetables and mushrooms ${ }^{\star 5}$ & $58 \pm 42$ & 18 & 320 & 181 & 32 \\
\hline Seaweed & $5 \pm 5$ & 25 & 20 & 9 & 56 \\
\hline Beans & $72 \pm 81$ & 72 & 100 & 50 & 84 \\
\hline Seafood & $37 \pm 28$ & 22 & 120 & 55 & 67 \\
\hline Meat & $98 \pm 44$ & 82 & 120 & 167 & 58 \\
\hline Eggs & $13 \pm 6$ & 16 & 80 & 50 & 26 \\
\hline Milk & $164 \pm 88$ & 66 & 250 & 179 & 92 \\
\hline Fruits & $90 \pm 84$ & 41 & 220 & 93 & 97 \\
\hline $\begin{array}{c}\text { Confectionary, Taste Beverage, } \\
\text { Sugar }{ }^{\star 5}\end{array}$ & $159 \pm 113$ & 29 & 557 & 496 & 32 \\
\hline Oils, Seeds ${ }^{\star 5}$ & $13 \pm 6$ & 65 & 20 & 18 & 72 \\
\hline Seasonings, Spices & $34 \pm 27$ & 38 & 90 & 90 & 38 \\
\hline
\end{tabular}

$\mathrm{n}=5 .{ }^{* 1} \mathrm{In} / \mathrm{St}$ : Intake quantity/Standard value. ${ }^{* 2}$ Excel Nutrition Food Frequency Survey; Standard Value by FFQ Ver. 3.5. ${ }^{* 3}$ Overview of the National Health Nutrition Survey of the Ministry of Health, Labor, and Welfare in 2012. ${ }^{\star 4}$ Intake ratio of subjects to 15 - 19-year-old participants in the National Health and Nutrition Survey result from the Ministry of Health, Labor, and Welfare in 2012. ${ }^{\star 5}$ Classified as a similar nutrient food group; the intake amount was set as the total value. 
Table 10. Food intakes of female cross-country skiers.

\begin{tabular}{|c|c|c|c|c|c|}
\hline \multirow[t]{2}{*}{ Nutrition } & \multirow{2}{*}{$\begin{array}{c}\text { Intake } \\
\text { quantity } \\
(\text { mean } \pm \mathrm{SD})\end{array}$} & \multirow{2}{*}{$\begin{array}{l}\text { In/St } \\
(\%)^{* 1}\end{array}$} & \multirow{2}{*}{$\begin{array}{l}\text { Standard } \\
\text { value } \\
(\mathrm{g})^{\star 2}\end{array}$} & \multicolumn{2}{|c|}{$\begin{array}{c}\text { National Health Survey and } \\
\text { Nutrition Examination Survey } \\
15 \text { - } 19 \text {-year-olds }\end{array}$} \\
\hline & & & & Intake quantity & Ratio $(\%)^{* 4}$ \\
\hline Cereals & $405 \pm 37$ & 65 & 620 & 410 & 99 \\
\hline Corms & $24 \pm 9$ & 30 & 80 & 52 & 46 \\
\hline Brightly colored vegetables & $88 \pm 52$ & 63 & 140 & 78 & 113 \\
\hline Other vegetables and mushrooms ${ }^{\star 5}$ & $193 \pm 92$ & 69 & 280 & 174 & 111 \\
\hline Seaweed & $4 \pm 3$ & 27 & 15 & 8 & 50 \\
\hline Beans & $69 \pm 26$ & 77 & 90 & 39 & 177 \\
\hline Seafood & $43 \pm 40$ & 39 & 110 & 49 & 88 \\
\hline Meat & $115 \pm 37$ & 115 & 100 & 119 & 67 \\
\hline Eggs & $37 \pm 19$ & 62 & 60 & 43 & 88 \\
\hline Milk & $155 \pm 58$ & 70 & 220 & 141 & 110 \\
\hline Fruits & $71 \pm 49$ & 36 & 200 & 83 & 86 \\
\hline $\begin{array}{c}\text { Confectionary, Taste Beverage, } \\
\text { Sugar }{ }^{* 5}\end{array}$ & $257 \pm 138$ & 52 & 492 & 390 & 66 \\
\hline Oils, Seeds ${ }^{\star 5}$ & $24 \pm 11$ & 141 & 17 & 12 & 200 \\
\hline Seasonings, Spices & $22 \pm 10$ & 28 & 80 & 75 & 29 \\
\hline
\end{tabular}

$\mathrm{n}=10 .{ }^{* 1} \mathrm{In} / \mathrm{St}$ : Intake quantity/Standard value. ${ }^{\star 2}$ Excel Nutrition Food Frequency Survey; Standard Value by FFQ Ver. 3.5. ${ }^{* 3}$ Overview of the National Health Nutrition Survey of the Ministry of Health, Labor, and Welfare in 2012. ${ }^{* 4}$ Intake ratio of subjects to 15 - 19-year-old participants in the National Health and Nutrition Survey result from the Ministry of Health,. Labor, and Welfare in 2012. ${ }^{\star 5}$ Classified as a similar nutrient food group; the intake amount was set as the total value.

Table 11. Food intakes of female speed skaters.

\begin{tabular}{|c|c|c|c|c|c|}
\hline \multirow[t]{2}{*}{ Nutrition } & \multirow{2}{*}{\multicolumn{2}{|c|}{$\begin{array}{l}\text { Intake quantity In/St } \\
\left(\text { mean } \pm \text { SD) }(\%)^{\star 1}\right.\end{array}$}} & \multirow{2}{*}{$\begin{array}{l}\text { Standard } \\
\text { value } \\
(\mathrm{g})^{\star 2}\end{array}$} & \multicolumn{2}{|c|}{$\begin{array}{l}\text { National Health Survey and } \\
\text { Nutrition Examination Survey } \\
15-19 \text {-year-olds }\end{array}$} \\
\hline & & & & Intake quantity & Ratio $(\%)^{\star 4}$ \\
\hline Cereals & $429 \pm 36$ & 69 & 620 & 410 & 105 \\
\hline Corms & $9 \pm 14$ & 8 & 80 & 52 & 17 \\
\hline Brightly colored vegetables & $63 \pm 28$ & 45 & 140 & 78 & 81 \\
\hline Other vegetables and mushrooms ${ }^{\star 5}$ & $93 \pm 70$ & 33 & 280 & 174 & 53 \\
\hline Seaweed & $1 \pm 1$ & 7 & 15 & 8 & 13 \\
\hline Beans & $20 \pm 14$ & 22 & 90 & 39 & 51 \\
\hline Seafood & $38 \pm 14$ & 35 & 110 & 49 & 78 \\
\hline Meat & $114 \pm 69$ & 114 & 100 & 119 & 96 \\
\hline Eggs & $18 \pm 8$ & 30 & 60 & 43 & 42 \\
\hline Milk & $158 \pm 104$ & 72 & 220 & 141 & 112 \\
\hline Fruits & $62 \pm 32$ & 31 & 200 & 83 & 75 \\
\hline $\begin{array}{c}\text { Confectionary, Taste Beverage, } \\
\text { Sugar }^{\star 5}\end{array}$ & $107 \pm 77$ & 22 & 492 & 390 & 27 \\
\hline Oils, Seeds ${ }^{\star 5}$ & $15 \pm 8$ & 88 & 17 & 12 & 125 \\
\hline Seasonings, Spices & $13 \pm 7$ & 16 & 80 & 75 & 17 \\
\hline
\end{tabular}

$\mathrm{n}=4 .{ }^{* 1} \mathrm{In} / \mathrm{St}$ : Intake quantity/Standard value. ${ }^{\star 2}$ Excel Nutrition Food Frequency Survey; Standard Value by FFQ Ver. 3.5. ${ }^{\star 3}$ Overview of the National Health Nutrition Survey of the Ministry of Health, Labor, and Welfare in 2012. ${ }^{* 4}$ Intake ratio of subjects to 15 - 19-year-old participants in the National Health and Nutrition Survey result from the Ministry of Health, Labor, and Welfare in $2012 .{ }^{\star 5}$ Classified as a similar nutrient food group; the intake amount was set as the total value. 
Table 12. Confectionery, preference drink, and sugar intakes of male cross-country skiers.

\begin{tabular}{|c|c|c|c|c|c|}
\hline \multirow{3}{*}{ Nutrition } & \multirow{3}{*}{$\begin{array}{c}\text { Intake quantity } \\
(\text { mean } \pm S D)\end{array}$} & \multirow{3}{*}{$\begin{array}{l}\text { In/St } \\
(\%)^{* 1}\end{array}$} & \multirow{3}{*}{$\begin{array}{l}\text { Standard } \\
\text { value } \\
(\mathrm{g})^{\star 2}\end{array}$} & \multirow{2}{*}{\multicolumn{2}{|c|}{$\begin{array}{c}\text { National Health Survey and } \\
\text { Nutrition Examination Survey*3 } \\
15-19 \text {-year-olds }\end{array}$}} \\
\hline & & & & & \\
\hline & & & & Intake quantity & Ratio $(\%)^{* 4}$ \\
\hline Confectionary & $128 \pm 76$ & 256 & 50 & 34.4 & 371 \\
\hline Taste Beverage & $152 \pm 94$ & 34 & 450 & 454.9 & 33 \\
\hline Sugar & $9 \pm 6$ & 129 & 7 & 6.8 & 132 \\
\hline
\end{tabular}

$\mathrm{n}=18 .{ }^{* 1} \mathrm{In} / \mathrm{St}$ : Intake quantity/Standard value. ${ }^{* 2}$ Excel Nutrition Food Frequency Survey; Standard Value by FFQ Ver. 3.5. ${ }^{* 3}$ Overview of the National Health Nutrition Survey of the Ministry of Health, Labor, and Welfare in 2012. ${ }^{* 4}$ Intake ratio of subjects to 15 - 19-year-old participants in the National Health and Nutrition Survey result from the Ministry of Health, Labor, and Welfare in 2012.

Table 13. Confectionery, preference drink, and sugar intakes of male speed skaters.

\begin{tabular}{|c|c|c|c|c|c|}
\hline \multirow{3}{*}{ Nutrition } & \multirow{3}{*}{$\begin{array}{l}\text { Intake quantity } \\
(\text { mean } \pm \text { SD })\end{array}$} & \multirow{3}{*}{$\begin{array}{l}\text { In/St } \\
(\%)^{* 1}\end{array}$} & \multirow{3}{*}{$\begin{array}{l}\text { Standard } \\
\text { value } \\
(\mathrm{g})^{\star 2}\end{array}$} & \multirow{2}{*}{\multicolumn{2}{|c|}{$\begin{array}{c}\text { National Health Survey and } \\
\text { Nutrition Examination Survey } \\
15 \text { - 19-year-olds }\end{array}$}} \\
\hline & & & & & \\
\hline & & & & Intake quantity & Ratio $(\%)^{* 4}$ \\
\hline Confectionary & $68 \pm 40$ & 136 & 50 & 34.4 & 198 \\
\hline Taste Beverage & $89 \pm 77$ & 20 & 450 & 454.9 & 20 \\
\hline Sugar & $2 \pm 2$ & 29 & 7 & 6.8 & 29 \\
\hline
\end{tabular}

$\mathrm{n}=5 .{ }^{* 1} \mathrm{In} / \mathrm{St}$ : Intake quantity/Standard value. ${ }^{* 2}$ Excel Nutrition Food Frequency Survey; Standard Value by FFQ Ver. 3.5. ${ }^{* 3}$ Overview of the National Health Nutrition Survey of the Ministry of Health, Labor, and Welfare in 2012. ${ }^{* 4}$ Intake ratio of subjects to 15 - 19-year-old participants in the National Health and Nutrition Survey result from the Ministry of Health, Labor, and Welfare in 2012.

Table 14. Confectionery, preference drink, and sugar intakes of female cross-country skiers.

\begin{tabular}{|c|c|c|c|c|c|}
\hline \multirow{3}{*}{ Nutrition } & \multirow{3}{*}{$\begin{array}{l}\text { Intake quantity } \\
\text { (mean } \pm \mathrm{SD})\end{array}$} & \multirow{3}{*}{$\begin{array}{l}\text { In/St } \\
(\%)^{\star 1}\end{array}$} & \multirow{3}{*}{$\begin{array}{c}\text { Standard } \\
\text { value } \\
(\mathrm{g})^{\star 2}\end{array}$} & \multicolumn{2}{|c|}{$\begin{array}{c}\text { National Health Survey and } \\
\text { Nutrition Examination Survey }\end{array}$} \\
\hline & & & & \multicolumn{2}{|c|}{15 - 19-year-olds } \\
\hline & & & & Intake quantity & Ratio $(\%)^{\star 4}$ \\
\hline Confectionary & $75 \pm 36$ & 214 & 35 & 34.8 & 216 \\
\hline Taste Beverage & $171 \pm 111$ & 33 & 450 & 382.5 & 45 \\
\hline Sugar & $4 \pm 4$ & 57 & 7 & 6.6 & 61 \\
\hline
\end{tabular}

$\mathrm{n}=10 .{ }^{* 1} \mathrm{In} / \mathrm{St}$ : Intake quantity/Standard value. ${ }^{* 2}$ Excel Nutrition Food Frequency Survey; Standard Value by FFQ Ver. $3.5{ }^{* 3}$ Overview of the National Health Nutrition Survey of the Ministry of Health, Labor, and Welfare in 2012. ${ }^{\star 4}$ Intake ratio of subjects to 15 - 19-year-old participants in the National Health and Nutrition Survey result from the Ministry of Health, Labor, and Welfare in 2012.

Asked about the question of whether or not to eat food or cereals, everyone answered, When asked "Are you eating enough?", all of the subjects except female cross-country skiers responded affirmatively. Also, more than $50 \%$ of participants in all groups answered that tried to consume milk. More than $75 \%$ and $65 \%$ of all respondents respectively answered the questions "Are you trying to 
Table 15. Confectionery, preference drink, and sugar intakes of female speed skaters.

\begin{tabular}{|c|c|c|c|c|c|}
\hline \multirow[t]{2}{*}{ Nutrition } & \multirow[t]{2}{*}{$\begin{array}{l}\text { Intake quantity } \\
(\text { mean } \pm \mathrm{SD})\end{array}$} & \multirow[t]{2}{*}{$\begin{array}{l}\mathrm{In} / \mathrm{St} \\
(\%)^{* 1}\end{array}$} & \multirow{2}{*}{$\begin{array}{l}\text { Standard } \\
\text { value } \\
(\mathrm{g})^{\star 2}\end{array}$} & \multicolumn{2}{|c|}{$\begin{array}{c}\text { National Health Survey and } \\
\text { Nutrition Examination Survey } \\
15 \text { - 19-year-olds }\end{array}$} \\
\hline & & & & Intake quantity & Ratio $(\%)^{* 4}$ \\
\hline Confectionary & $60 \pm 60$ & 171 & 35 & 34.8 & 172 \\
\hline Taste Beverage & $46 \pm 70$ & 10 & 450 & 382.5 & 12 \\
\hline Sugar & $2 \pm 1$ & 29 & 7 & 6.6 & 30 \\
\hline
\end{tabular}

$\mathrm{n}=4 .{ }^{* 1} \mathrm{In} / \mathrm{St}$ : Intake quantity/Standard value ${ }^{\star 2}$ Excel Nutrition Food Frequency Survey; Standard Value by FFQ Ver. $3.5{ }^{* 3}$ Overview of the National Health Nutrition Survey of the Ministry of Health, Labor, and Welfare in 2012. ${ }^{* 4}$ Intake ratio of subjects to 15 - 19-year-old participants in the National Health and Nutrition Survey result from the Ministry of Health, Labor, and Welfare in 2012.

Table 16. Consciousness of eating habits.

\begin{tabular}{|c|c|c|c|c|}
\hline \multirow{3}{*}{$(\%)$} & \multicolumn{2}{|c|}{ Cross-country skiers } & \multicolumn{2}{|c|}{ Speed skaters } \\
\hline & Male & Female & Male & Female \\
\hline & $\mathrm{n}=18$ & $\mathrm{n}=10$ & $\mathrm{n}=5$ & $\mathrm{n}=4$ \\
\hline \multicolumn{5}{|c|}{ Appropriate body weight } \\
\hline Known & 39 & 60 & 80 & 75 \\
\hline Unknown & 61 & 40 & 20 & 25 \\
\hline \multicolumn{5}{|l|}{ Think about nutrition } \\
\hline Think carefully & 22 & 30 & 80 & 75 \\
\hline Sometimes think & 50 & 50 & 20 & \\
\hline Do not think & 28 & 20 & & 25 \\
\hline \multicolumn{5}{|c|}{ Main dish, side dish combination } \\
\hline Habitually & 28 & & & \\
\hline Often & 39 & 70 & 20 & 25 \\
\hline Sometimes & 22 & 20 & 80 & 50 \\
\hline Almost never & 11 & 10 & & 25 \\
\hline \multicolumn{5}{|c|}{$\begin{array}{l}\text { So that there is no bias } \\
\text { in the cooking method }\end{array}$} \\
\hline Habitually & 28 & 20 & & 25 \\
\hline Often & 39 & 40 & 60 & 25 \\
\hline Sometimes & 17 & 40 & 20 & 50 \\
\hline Almost never & 17 & & 20 & \\
\hline \multicolumn{5}{|l|}{ Meal time } \\
\hline Is confirmed & 89 & 90 & 80 & 100 \\
\hline Not determined & 11 & 10 & 20 & \\
\hline \multicolumn{5}{|l|}{ Absence of meals } \\
\hline Not at all & 100 & 100 & 100 & 100 \\
\hline Hardly & & & & \\
\hline
\end{tabular}




\section{Continued}

Eat until full

Yes

No

Appropriate amount of snack

Reasonable amount

More

Unknown

Quality of eating habits

Very good

Good

Acceptable

Slightly problematic

Eat rice regularly

Have enough to eat

Have not eaten

Drinking milk

I remember to do this

Sometimes I remember

Not much

Eating beans

I remember to do this

Sometimes I remember

Not much

Eating vegetables

I remember to do this

Sometimes I remember

Not much

Eating fruits

I remember to do this

Sometimes I remember

Not much

Not at all

eat vegetables?" and "Are you trying to eat fruits?" "We try to remember to eat them."

\section{Discussion}

The relationship between cross-country skiing and speed-skating ability and 
stamina is very strong. Additionally, the correlation between athletic performance and the maximum oxygen intake is very strong, as competitiveness is highly dependent on oxygen uptake [19]. Among male participants in this study, the speed skaters were significantly higher than that of cross-country skiers. By contrast, no significant difference was observed between the female athletes. Furthermore, a definite relationship was established among an individual's $\mathrm{VO}_{2} \max$, body fat percentage, fat quantity, fat amount, and muscle mass. Reports describe body fat percentages of $11 \%$ - $13 \%$ among male athletes and $22 \%$ $24 \%$ among female athletes. Speed skaters in the present study had slightly higher body fat percentages. Buskirk and Taylor [20] also focused on the relationship between the $\mathrm{VO}_{2}$ max and fat. Relative to a slimmer person, an obese person has a higher the $\mathrm{VO}_{2} \mathrm{max}$; however, the $\mathrm{VO}_{2} \max$ per body weight is higher in the obese person than in the slimmer person, and the value of the $\mathrm{VO}_{2} \mathrm{max}$ is almost equal to the value of the leaner. Furthermore, among study subjects whose body fat ratios differed from the body fat, the body weight was lower as the body weight is heavier. The results observed for female cross-country skiers and speed skaters in our study are similar to those from earlier studies, suggesting that an increase in fat weight loss is needed to improve the $\mathrm{VO}_{2} \max$. However, we did not observe a similar relationship between weight and body fat among male cross-country skiers and speed skaters [21]. In this study, we did not observe significant differences in the maximum lactic acid levels at the highest oxygen intakes, suggesting that cross-country skiers and speed skaters do not differ in terms of oxygen levels.

A diet survey was conducted to determine the PALs and nutritional statuses of high school-level female speed skaters and female golfers. As a result, the standards exceeded the PAL level of 2.00 (1.90 to 2.20) in all categories of Japanese meal intake standards in 2010. Saito et al. [22] measured overall daily consumption of Sports and PAL in the dual-marker Water Act and reported PALs ranging from $1.7-2.5$, as well as PALs exceeding 2.5. This suggests that the survey results may have resulted from the results of the survey as a result of the study of the survey results in the survey of food intake frequency, and the number of players with high training results differs from that of many athletes with higher levels of training. By contrast, the average energy intake reported in the food intake frequency survey was below the normal range in all groups.

In 2009 statement, the American Society for Sports Medicine recommended that the protein intakes of endurance athletes should be based on data from a study of nitrogen balance [23]. The average intake of protein in the present study exceeded the Japanese dietary standard of 2.00 (1.90 - 2.20) in 2010. In 2012, however, less protein was consumed by the same age skater than in the same period of protein intake in the National Health and Nutrition Survey. In a previous study, Lemon [24] reported the risk of vitamin and mineral deficiencies at a protein intake level of $<12 \%$. The study found that the protein ratio in the target population was below $12 \%$. However, it is difficult to determine the amount of 
protein required by athletes. During aerobic training, it is reported that the disappearance of the amino acid in the exercise of the amino acid during exercise is restrained compared with the initial training of the trained person [25].

Sports players must consume sufficient amounts of sugar to replenish the energy needed for training and competition. Current recommendations suggest that they should consume $>5.5$ grams of sugar per $\mathrm{kg}$ of body weight [26]. In this study, the standard intake was lower than the standard Japanese dietary intake (1.90 to 2.20) and higher than the standard of the Japanese diet (1.90 to 2.20). When I looked at the amount of weight per kilogram, I found myself in less than a cross country skiing man. In this study, although the carbohydrate energy ratios were within the range of reference values, the grain energy ratios of all target groups were less than the reference values. Glucose can be used as energy sources. All groups in this study consumed particularly large amounts of glucose, or 1.72 - 3.71 times the levels of other peers of both sexes. The tendency to supplement energy shortages using energy derived from grains was identified as a preference for confectionery.

Although the grain energy ratio data suggested an insufficient carbohydrate intake, all subjects responded that "Are you eating enough food and cereals" except for Cross-Country Ski Championships? Ina survey regarding sweets, half of the respondents reported that their consumption levels were adequate. Even an individual who is conscious of the amount of grain consumed might not understand the amount of food that should be consumed each day or a loss of appetite due to fatigue. Snacks should be selected to satisfy energy and provide nutrients that cannot be consumed in only three meals. First, grains (e.g., corn) should be consumed during meals. Reports suggest that dietary carbohydrate intake and subsequent absorption are essential to full fatigue recovery [26]. While the meal is growing, the problems of eating and eating are increasing, and the problems of eating alone are reported [27].

\section{Conclusion}

Nutrition guidance should be provided based on athletes' livelihoods. The study participants were able to eat meals without eating meals. Additionally, many people reported that they thought about nutrition. The survey revealed that the dietary consciousness and efforts of the researchers, as well as the nutritional intakes of the study subjects, were biased.

\section{References}

[1] Higuchi, M. (1998) Sports Nutrition to Utilize on Site. The Journal of Health, Physical Education, and Recreation, 48, 839-842.

[2] Kimura, M., Adachi, M. and Tomiyasu, U. (2007) Junior Players' Nutrition and Diet Guidance Practice. Japanese Society of Clinical Sports Medicine, 15, 204-210.

[3] Hiragawa, F., Takemoto, A. and Hayabuchi, H. (2008) Role of Administrative Dietician in Health Management of Professional Baseball Team. Japanese Society of Clinical Sports Medicine, 16, 349-359. 
[4] Koshimizu, T. (2007) Top Sports Athletes' Nutrition and Diet Management. Japanese Society of Clinical Sports Medicine, 15, 211-215.

[5] Takamatsu, R. and Takato, Y. (2000) Food Management of Athletes. Health Science, 42, 353-358.

[6] (2007) Japan Sport Council: The FY 2005 Student Survey Report, Published by School Children in FY 2011.

[7] Iide, K., et al. (2009) Nutritional Survey in University Male Soccer Players. Bulletin of International Pacific University, 2, 65-70.

[8] Imamura, H., et al. (1997) On the Nutrient Intake Status and Serum Enzyme Activity of University Karatedo Players. Japan Society of Exercise and Sports Physiology, $4,1-7$.

[9] Miyamoto, N., et al. (2004) On the Nutrient Intake and Body Composition of High School Female Gymnasts. Bulletin of Nakamura Gakuen University, Nakamura Gakuen University Junior College, 36, 215-218.

[10] Sekine, T., et al. (2001) Relationship between Vitamin B1, B2, C Intake and Vitamin Nutritional Status in University Women's Tennis Players. The Japanese Journal of Nutrition and Dietetics, 59, 79-86.

[11] Shimosato, S., Ishimi, M. and Nasu, M. (2006) Survey on Actual Condition of Intake Energy and Nutrient Amount for Athletes (2nd Report). Departmental Bulletin Paper, 13, 13-30.

[12] Leblanc, J.C., et al. (2002) Nutritional Intake of French Soccer Players at the Claire Fontaine Training Center. International Journal of Sport Nutrition and Exercise Metabolism, 12, 268-280. https://doi.org/10.1123/ijsnem.12.3.268

[13] Hiragawa, F. and Yoshihara, Y. (2008) Body Composition of Eating Athletes, Dietary Habits and Nutrient Intake Situation and Issues. Memoirs of the Beppu University, 49, 83-92.

[14] Takahashi, K. (2003) Preparation of Food Intake Survey Table for Estimating Intake by Nutrient and Food Group. The Japanese Journal of Nutrition and Dietetics, 61, 161-169.

[15] Ministry of Health, Labor, and Welfare (2009) The Standard for Dietary Intake of Japanese People. Daiichi Syuppan, Tokyo.

[16] Keul, J., Doll, E. and Keppler, D. (1972) Energy Metabolism of Human Muscle. Karger, Basel.

[17] Cunningham, D.A. and Faulkner, J.A.A. (1969) Aerobic and Anaerobic Metabolism during a Short Period of Time. Medicine and Science in Sports, 1, 65-69.

[18] Saltin, B. and Astrrand, P.O.P. (1967) Upstream, Athletes. Journal of Applied Physiology, 23, 353-358. https://doi.org/10.1152/jappl.1967.23.3.353

[19] Kuroda, Y. (1973) The Sapporo Olympic Sports Research Report. Japan Amateur Sports Association, Tokyo.

[20] Buskirk, E. and Taylor, H.L. (1957) Maximal Oxygen Intake and Its Relation to Body Composition with Special Reference to Chronic Physical Activity and Obesity. Journal of Applied Physiology, 11, 72-78. https://doi.org/10.1152/jappl.1957.11.1.72

[21] Williams, C.G., Wyndham, C.H. Morrison, J. and Heyns, F.A. (1966) The Influence of Weight and of Stature on the Mechanical Efficiency of Men. Internationale Zeitschrift für angewandte Physiologie, einschliesslich Arbeitsphysiologie, 23, 107-124. https://doi.org/10.1007/BF00699300

[22] Saito, S., et al. (1999) Principle of Measurement of Energy Consumption by Double 
Labeled Water Method and Its Application: From Measures for Lifestyle Diseases to Nutritional Prescription of Top Athletes. The Japanese Journal of Nutrition and Dietetics, 57, 317-332.

[23] Rodriguez, N.R., et al. (2009) American College of Sports Medicine Position Stand. Nutrition and Athletic Performance. Medicine and Science in Sports and Exercise, 41, 709-731.

[24] Lemon, P.W. (1994) Protein Requirements of Soccer. Journal of Sports Science, 12, S17-S22.

[25] McKenzie, S., et al. (2000) Endurance Exercise Training Attenuates Leucine Oxidation and BCO-AD Activation during Exercise in Humans. American Journal of Physiology, Endocrinology and Metabolism, 278, E580-E587.

https://doi.org/10.1152/ajpendo.2000.278.4.E580

[26] Burke, L.M. (2003) The IOC Consensus on Sports Nutrition 2003: New Guidelines for Nutrition for Athletes. International Journal of Sport Nutrition and Exercise Metabolism, 13, 549-552. https://doi.org/10.1123/ijsnem.13.4.549

[27] Taguchi, M. and Kobata, T. (2005) Introduction to Meals for Games. Journal of Health, Physical Education and Recreation, 50, 65-70. 